\title{
Kolażowa tożsamość medialna
}

ABSTRACT. Błaszczak Monika, Kolażowa tożsamość medialna [The collage media identity]. "Przestrzenie Teorii" 10. Poznań 2008, Adam Mickiewicz University Press, pp. 75-103. ISBN 978-83-232-1946-0. ISSN 1644-6763.

Mirrors and screens have affected the specific of knowing, especially of dramatical characters' selfknowing. The personages are trying to walk through selfknowing, they are searching their identity asking themselves where is their "ego". They want to see their real image in the mirror reflections. The process of growing the identity up which has taken place in the confrontation with the mirror reflection that calls Lacan's interpretation, who tells about Mirror Phase as an indispensable stage of "me" moulding. But the anagnorisis can't take place anymore. The character in mirror-screened space faces the problem of creating his own "ego" not only from the fragment of the reality given to him directly in the dialogue and relations with other characters but also in the face of his mirror's reflection and copies in video projections. Besides selfknowing inspiration, the problem of selfreflection in its works also appears. The memory is also the sort of mirror where the written pictures sometimes blur. In the contexts of contemporary "screened" dramas, the identity of character reaches the stage which we can call multicomplications. The character is shown as a dynamic dramatical space - the battle between the subject sphere and the object sphere. Breakdown and the lack of cohesion become the leading rule of character's creating, where in the end looks like collage. New dramatical identity has arisen - the collage media identity.

$\mathrm{Na}$ początku było lustro, a potem pojawił się ekran. Parafrazując jednocześnie określenie Jacques’a Lacana i słowa Jeana Baudrillarda powiedzieć by wręcz można, że „faza lustra przeszła w stadium ekranu”. Wydaje się, że mamy dzisiaj do czynienia $z$ kształtowaniem się nowej estetyki dramatycznej opartej na lustrzano-ekranowej grze. Lustra, a obecnie coraz częściej ekrany otwierają szerokie pole zagadnień dotyczących współczesnej dramaturgii. Jednym z najważniejszych zagadnień dramatycznych jest z pewnością kwestia postaci. Obecność luster i ekranów bardzo silnie i znacząco wpłynęła na specyfikę poznania, a zwłaszcza samopoznania dramatycznych postaci i na charakter ich tożsamościowych poszukiwań.

\section{Gdzie jest moja twarz? - anagnorisis w błysku światła}

Postać dramatyczna w lustrzano-ekranowej przestrzeni staje wobec problemu swojej tożsamości. Musi ją kształtować już nie tylko z fragmentów rzeczywistości danej jej bezpośrednio w dialogu i relacjach $\mathrm{z}$ innymi postaciami, ale $\mathrm{w}$ stosunku do swojego odbicia w lustrze oraz powieleń $w$ projekcjach wideo. Nowe typy przestrzeni dramatycznych 
i teatralnych powołują nowe typy postaci. Stają one wobec tożsamościowych wyzwań, które stawia im bardzo specyficzny obszar.

Postać przede wszystkim staje wobec wyzwania rozpoznania. Arystoteles wprowadził tę kategorię jako istotny składnik tragedii, stanowiący kulminacyjny moment akcji dramatycznej. W Poetyce grecki myśliciel wyjaśnia, czym jest dla niego rozpoznanie (anagnórisis):

Rozpoznanie zaś, jak sama nazwa wskazuje, jest to zwrot od nieświadomości ku poznaniu, który prowadzi do przyjaźni lub wrogości między postaciami, których stan szczęścia lub nieszczęścia został uprzednio [przez poetę] określony ${ }^{1}$

Znamienne, że to właśnie rozpoznanie połączone z perypetią (zmianą biegu zdarzeń przeciwną do kierunku działań postaci) może wzbudzić tak pożądaną litość i trwogę i że wzorcową realizacją jest historia Edypa. Oczywiście można podać więcej przykładów tego typu rozpoznania (Hekaba czy Herakles Szalony Eurypidesa), ale to właśnie dzieje Edypa są tą idealną i najbardziej poruszającą historią rozpoznania - uzyskania świadomości zabicia własnego ojca i poślubienia matki. Arystoteles podaje w sumie sześć rodzajów rozpoznania, wyraźnie je wartościując. Pisze zatem o rozpoznaniu za pośrednictwem znaków zewnętrznych, które uznaje za najmniej artystyczne. Znaki wrodzone (znamiona) lub nabyte (blizny na ciele bądź przybrane z zewnątrz: naszyjniki, wanienka). Drugi typ to rozpoznanie, które wprowadza poeta wedtug swej woli - nieartystyczne (np. na podstawie listu). Kolejne to rozpoznania taczqce się $z$ przypomnieniem, dzięhi któremu na widok czegoś ujawnia się uczucia (np. pieśń aojda czy widok obrazu zdradza prawdziwe oblicze bohatera), rozpoznania oparte na sylogistycznym wnioskowaniu (np. skoro przybywa ktoś do mnie podobny, a tylko mój brat wykazuje takie podobieństwo, to musi być on), rozpoznanie połqczone $z$ błęnym rozumowaniem publiczności (paralogizmem) - polegające na opieraniu się jedynie na wymyśle poety. Za najdoskonalsze Arystoteles uznaje rozpoznanie, które wynika $z$ samych zdarzen - Edyp dokonuje szokującego dla siebie odkrycia, które jest następstwem naturalnego rozwoju sytuacji. Zaraz za tym typem rozpoznania plasuje się to na podstawie sylogizmu². Wyłaniają się z tego obrazy przedstawiające typy sytuacji, w których: postacie są świadome swojej i innych tożsamości oraz własnych czynów; postacie są nieświadome wzajemnej tożsamości i dokonują rozpoznania dopiero po popełnieniu straszliwych, zbrodniczych czynów; postacie, które przed samym momentem popełnienia zbrodni rozpoznają swoją ofiarę, co je powstrzymuje od morderstwa.

${ }^{1}$ Arystoteles, Poetyka, przełożył i opracował H. Podbielski, Wydawnictwo Zakład Narodowy im. Ossolińskich, Wrocław 1983, s. 32.

2 Tamże, s. 47-50. 
Podążając tropem Arystotelesowskiego rozpoznania, problemy z tożsamością bohaterów współczesnych dramatów można wpisać w niektóre z kategorii nakreślonego przez greckiego filozofa porządku. Rozpoznanie bowiem pozwala na ustalenie swojej prawdziwej tożsamości, co prowadzi albo do pozytywnego ukonstytuowania własnego ,ja", albo do jego calkowitej dezintegracji.

Swiadomość siebie, własnego bytu nabywamy w lustrze. Szerokie pole rozważań teoriopoznawczych związanych $\mathrm{z}$ poszukiwaniem tożsamości otwiera właśnie lustro - jak mówi formuła św. Pawła:

Teraz widzimy niejasno jak w zwierciadle, potem zobaczymy bezpośrednio - twarzą w twarz ${ }^{3}$.

(I List św. Pawła do Kor. XIII, 12).

Autopostrzeganie początkowo odbywało się w tafli wody, w szybie, w oczach drugiego człowieka czy w kulturze swoich czasów. Później zastąpił je ekran - współczesna wersja lustra. Z lustrem jako narzędziem poznania łączą się tak ważne kategorie, jak rozświetlenie i światło. Polskie słowo lustro wywodzi się bowiem od łacińskiego lux tłumaczonego jako światło. Zjawisko światła to problem epistemologiczny, estetyczny i fizyczny, najbardziej elementarny. Epistemologia wprowadza poznanie jako olśnienie - claritas. Pierwszym, który wprowadza takie rozumienie, jest św. Augustyn, widząc w olśnieniu sposób poznania. Umysł ludzki był postrzegany metaforycznie jako zwierciadło świata. Swiatło odbite, lśnienie otwiera problem granicy między odbitym a odbijanym. Sfera liminalna rozciąga się w dramatach od jasności, blasku, pełnego światła, aż do przygasania i zaciemnienia. Zwierciadła lśnią odbitym blaskiem, stąd symbolizowaly $w$ pierwotnych kulturach boga-słońce. Blask, lśnienie w lustrze tak naprawdę oślepia, uniemożliwia spojrzenie, a więc rozpoznanie. Dopiero olśnienie pozwala na przeniknięcie przez lśnienie - zajrzenie na drugą stronę lustra.

Estetyka rozpatruje piękno jako blask, czyniąc $z$ lśnienia kategorię estetyczną. Swiatło przekształca obrazy rzeczywistości w sztukę, przez co odrywa ją od rzeczywistości, odrzuca realne odnośniki przedmiotów. Bachelard w płomieniu świecy dostrzega źródło obrazów: „płomień jest jednym $\mathrm{z}$ największych twórców obrazu"4. Twórczość - literacka, ale i w ogóle artystyczna - to lustro, w którym przegląda się twórca. Postrzeganie siebie i świata rozgrywa się przed powierzchnią lustra:

${ }^{3}$ Pismo Święte Nowego Testamentu, wstęp, nowy przekład z Wulgaty, komentarz ks. E. Dąbrowski, Poznań-Warszawa-Lublin 1959, s. 565.

${ }^{4}$ G. Bachelard, Plomień świecy, przekład J. Rogoziński, słowo / obraz terytoria, Gdańsk 1996, s. 7. 
przed zwierciadłem stoi człowiek rozdarty w swoim dylemacie ontologicznym: czym jest, jak się staje, co oznacza jego wnętrze, jak przedstawia się sobie i światu? Przed zwierciadlem stają słowa - ożywają, przyglądają się sobie, są wyrazem człowieka czy lustrem dla twórcy? ${ }^{5}$

Oprócz samopoznania - olśnienia pojawia się zatem problem odbicia siebie we własnej twórczości. Świetnie ten problem ilustruje wiersz Różewicza Zwierciadto:

\author{
żywe młode \\ teraz poczerniałe \\ martwe \\ umiera \\ bez odbicia \\ światła \\ oddechu $^{6}$
}

twarz którą widzę teraz

widzialem na początku

ale jej nie przewidziałem

lustro ukryło ją w sobie

Lustro staje się żywym tworem, które zrosło się z patrzącym podmiotem - odnajdującym w jego powierzchni własne przemijanie. Znakiem śmierci staje się brak odbicia, a co za tym i światła, na mocy którego ono powstaje. Cała twórczość może być postrzegana jako rodzaj iluminacji czy świetlnego refleksu odbijającego się na powierzchni lustra. Gdzie jest zatem prawda poznania? Różewicz daje odpowiedź zapośredniczoną poprzez lustro:

\author{
opisz swoją twarz \\ z pamięci \\ nie $\mathrm{z}$ lustra
}

w lustrze możesz pomylić prawdę $\mathrm{z}$ jej odbiciem ${ }^{7}$

Jednak pamięć to także rodzaj lustra, w którym zapisane obrazy z czasem zamazują się, tracą na wyrazistości lub zapadają w otchłanie podświadomości i niepamięci. Zatem wydają się raczej nikłe i iluzoryczne jak odbicia w lustrzanej tafli. Ludzki umysł rejestruje tylko wybrany

5 A. Krajewska, Dramaty lustrzane, w: Dwudziestowieczna ikonosfera w literaturach europejskich. Wizualizacja $w$ literaturze, pod red. B. Tokarz, Wydawnictwo "Sląsk", Katowice 2002, s. 398.

6 T. Różewicz, Zwierciadto, w: zawsze fragment. recycling, Wydawnictwo Dolnośląskie, Wrocław 1998, s. 89-90.

7 T. Róż e wic z, zadanie domowe, w: zawsze fragment. recycling, s. 55. 
fragment świata, gdyż postrzeganie ma charakter wybiórczy, selektywny. Pamięć oparta jest właśnie na takich selektywnych konstrukcjach obrazu świata zewnętrznego wytwarzanego we wnętrzu umysłu.

Odbicie w lustrze pamięci i czasu staje się również ważną zasadą konstrukcyjną dramatów. W Ostatniej taśmie Krappa Becketta lustrem stają się obrazy przeszłości, przywoływane poprzez odtwarzanie wspomnień nagranych na kasetach magnetofonowych oraz widziane w ludzkich oczach - poprzez światło widziane w oczach dawnej ukochanej. W Pułapce Różewicza kolażowy charakter tożsamości znajduje szczególnie ciekawą realizację. W procesie budowy i poszukiwania tożsamości nie ma tu jeszcze elementu medialności, ale mnożą się lustrzane powielenia i odbicia. Cała twórczość Różewicza to dramatyczne poszukiwania i zmagania z własnym, ja" samego twórcy.

W Putapce postać Kafki staje się jedynie pretekstem do autoanalizy. Głównym bohaterem pozornie wydaje się Franz. Występuje najpierw jako mały, około sześcioletni chłopiec szukający pocieszenia u służącej Józi (w Obrazie I), potem już jako nieco starszy (w Obrazie II. Po latach) w scenie obiadu. Oprócz swojego dziecięcego wcielenia przyjmuje też postać dorosłego na różnych etapach życia. Po pierwsze występuje jako młody doktor praw i pisarz uwikłany w ciąg zaręczyn i ich zrywania z Felice, z pomywaczką Janą, może z Gretą. Tożsamości narzeczonych przenikają się nawzajem, tworząc obraz jednego nieosiągalnego ideału, który stwarza sobie Franz po to, aby go nigdy nie móc odnaleźć. Poza tym pojawia się jako schorowany umierający człowiek, proszący przyjaciela o spalenie reszty swoich rękopisów. Ma twarz chłopca, narzeczonego, samca, pisarza, prokurenta (urzędnika), doktora praw, przyjaciela i syna, a wreszcie żydowskiej ofiary holocaustu. Pojawia się też w sferze pozarzeczywistej - jako własne senne widzenie, czyli „duszyczka”. Sni o sobie jako baranku ofiarnym, którego ma zamiar poswięcić własny ojciec. Po obudzeniu się $z$ tego snu wypowiada znamienne słowa, świadczące o jego własnym poczuciu dezintegracji tożsamości:

... Chcę być Twoim dzieckiem... widzę, jestem słaby, rozpadam się, rozkładam, boję się ludzi, boję się Ciebie...8

„Duszyczka”, którą widzi we śnie, to część jego „ja”, która jest zarówno wcieleniem dziecięcej niewinności, jak i uosobieniem zdystansowania i obojętności zewnętrznego obserwatora wydarzeń.

Ale to nie Franz jest tu najważniejszy - jest jedynie pretekstem, punktem scalającym „teatr wewnętrzny” Różewicza. Udramatyzowane zmagania wewnętrzne dotyczą roli i funkcji artysty oraz sytuacji czło-

8 T. Różewicz, Pulapka, w: tegoż, Dramat 3, Wydawnictwo Dolnośląskie, Wroclaw 2005, s. 222. 
wieka wobec traumy wojny. Czarna ściana raz po raz rozsuwa się, a na jej tle pojawiają się Oprawcy i sceny prześladowań. Jednak sam pisarz nie był $\mathrm{w}$ obozie, zatem obrazy te są projekcją przeżyć znanych $\mathrm{z}$ relacji innych.

Pułapką okazuje się nie tylko ciało, nie tylko szafa, jako metaforyczny odpowiednik małżeńskiego pożycia i schronu przeciwholocaustowego, ale przede wszystkim świat psychiczny, wewnętrzny. Pułapka to jednak nie zamknięcie, jak widzi to Ottla, ale kalejdoskopowość i nieuchwytność tożsamości - utkanej $\mathrm{z}$ wielu wersji. Tą specyficzną wielowymiarową i wieloczęściową strukturę podkreślają jeszcze lustrzane elementy obecne w dramacie. Małe lusterko wisi w pokoju Służącej Józi, lustro musi się też pojawić jako część kompletu mebli kupowanych przez Franza i Felice. W lustrze w sklepie przegląda się Franz, poprawiając kapelusz, a także Sprzedawca ze sklepu meblowego, drapując krawat; Felice przed lustrem, zawieszonym $\mathrm{w}$ pokoju hotelowym zamieszkanym przez Franza, poprawia włosy, rozciera perfumy na ciele i ocenia swój wygląd; Greta czesze przed lustrem zmierzwione włosy i zmienia sukienkę po akcie gwałtu. Odbicie lustrzane przypomina chwilami fotografię, ale $w$ przeciwieństwie do niej jest absolutnie ulotne. W salonie fryzjerskim (w Obrazie XII. U Fryzjera) na ścianie wiszą dwa lustra, przed którymi stoją fotele dla klientów. W tej scenie twarz Franza widoczna jest wyłącznie jako lustrzane odbicie, co jeszcze bardziej podkreśla złożony i niepewny charakter jego tożsamości. Poprzez lustro kieruje swoje spojrzenie na sceny rozgrywające się za nim. Chwyt ten podkreśla dystans bohatera, jego pośredni udział w tych wydarzeniach, ale i wskazuje na ich fikcyjność, iluzoryczność - są tak okrutne, że aż nieprawdopodobne. Portret Ojca ukazujący go w czasach jego świetności (zawodowej, zdrowotnej, społecznej) - to również swoiste lustro: pamięci, przeszłości, wspomnień.

Światło odgrywa tu również ważną rolę - jest miejscem potencjalnej iluminacji, czyli poznania, ale i siłą zniszczenia w postaci ognia. Jadalnia, w której Ojciec z rodziną spożywa obiad, jest oświetlona lampą z abażurem w kwiaty - swoją barwnością kontrastuje z przesyconą negatywnymi emocjami sytuacją. W obrazie snu snop światła pada $z$ góry na stół, wydobywając go z przestrzeni czarnej pustki. Błysk złotych koronek na zębach Felice, widoczny, gdy ta się szeroko śmieje, przeraża Franza swoją cielesnością, fizjologiczną dosłownością, ale także czytelnika, gdy zostaje zderzony $\mathrm{z}$ obrazem wyrywania złotych koronek ze szczęk zagazowanych Żydów.

Ciemność to przestrzeń, w której skrywają się „zmory” za czarną ścianą - Oprawcy i ofiary obozu. Elli, Valii i Ottla znikają uprowadzone przez Oprawców, a scenę spowija podkreślające dramatyzm tej sceny oświetlenie: 
Scenę ogarnia powoli martwe, zimne światło. Barwy umierają. Wszystko zmienia się w dym, mglę. Popió1 ${ }^{9}$.

W czerwonym świetle ognia w piecu płoną rękopisy bohatera. Także poprzez kieliszek czerwonego wina, który trzyma w dłoni, prześwieca barwne światło i rzuca na jego twarz. Punktowe światło padające $z$ gołej żarówki stanowi narzędzie opresji - tortur (nad Panem w Obrazie II. U Fryzjera). Swiatło jest we wszystkich obrazach albo przytłumione, albo bardzo silne, jasne, nienaturalne - tak jak świat, w którym przyszło żyć bohaterom, tak jak myśli, wspomnienia, rozpoznania i ich brak.

Postacie przeglądają się nawzajem w sobie, poszczególne twarze Franza odbijają się i naświetlają, a jego postać rozbita na swoje czasowe wcielenia i "duszyczkę" staje się lustrem, w którym przegląda się sam dramaturg. To twarz „wieloobliczowa”, płynna, ale zarazem nieciągła, rozmywająca się i niejednorodna.

Twarz można widzieć także za pośrednictwem szyby pełniącej funkcję pośrednika spojrzenia, niczym lustro:

$$
\begin{aligned}
& \text { rzeczywistość } \\
& \text { którą oglądałem } \\
& \text { przez brudną szybę } \\
& \text { w poczekalni } \\
& \text { ujrzałem } \\
& \text { twarzą w twarz } \\
& \text { słaby } \\
& \text { odwróciłem się } \\
& \text { od mojej słabości } \\
& \text { odwróciłem się } \\
& \text { od zludzeń } \\
& \text { na piaskach } \\
& \text { moich słów } \\
& \text { ktoś nakreślił znak } \\
& \text { ryby } \\
& \text { i odszedł10 }
\end{aligned}
$$

Poznanie poprzez szybę czy lustro to poznanie pośrednie, pasywne, niedoskonałe, a ujrzenie twarzą w twarz to poznanie bezpośrednie, aktywne i prawdziwe. Poeta wykorzystuje tu „motywy niedoskonałej i zwodniczej reprezentacji, piękna i prawdy, dzieła jako zwierciadła i okna („szyby”)

9 Tamże, s. 258.

10 T. Różewicz, bez tytulu, w: tegoż, Poezja, t. 2, Wydawnictwo Literackie, Kraków 1988 (wiersz pochodzi z tomu Regio). 
na rzeczywistość"11. Forma wiersza to ślad, która zostawia swój odcisk w postaci przedstawiania. Zatem „Wiersz opowiada o czymś szczególnym, co się wydarzyło, wnioskując o tym $z$ odczytywanych pamięciowych śladów"12. Problem postawienia siebie twarzą w twarz z własnym ,ja" pojawia się już w pierwszych wersach dramatu Kajzara Gwiazda:

\author{
Jeszcze raz? \\ Jak w lusterku. Twarzą w twarz. \\ Tak. \\ Dokona się. \\ Słowo po słowie. \\ Dawniej i z pamięci. Mówićc ${ }^{13}$.
}

Już Witkacy eksperymentował z lustrem i lampą, powielając odbicia. Artysta był zafascynowany fotografią, co zwróciło jego uwagę na rolę światła.

Jednak kolor i światło w powieściach i dramatach Witkacego „żyją", są dynamiczne, mają raczej filmową niż fotograficzną proweniencję, gdyż ruch jest żywiolem filmu ${ }^{14}$.

Cała twórczość Witkacego - prozatorska, dramaturgiczna, eseistyczna, malarska i fotograficzna - to gra odbić i tożsamości. Gra, która rozgrywa się nie tylko na poziomie danego tekstu, ale między tekstami $\mathrm{z}$ różnych dziedzin twórczości artysty a jego własną teorią sztuki, aż po prywatne życie, włącznie z realnymi osobami: jego przyjaciółmi, wrogami, rywalami, rodziną. Polemizuje z filozofami, których dzieła czyta, wkładając ich wypowiedzi w usta bohaterów swoich dramatów. Swoją teorię estetyczną rozpisuje na dramatyczne głosy. Trzeba się zatem zastanowić, czy postać mówiąca jego „rzeczywistymi słowami” jest alter ego samego Witkacego czy stricte fikcyjnym tworem, i czy w ogóle da się od siebie oddzielić te elementy. Poszczególne postaci odbijają się i rozwijają w sobie nawzajem między tekstami, w nich z kolei znajdują nieraz swoje odbicie ich realne odpowiedniki oraz sam Witkacy poprzez swoją teorię, lektury i biografię. Tekst, ale i obrazy oraz fotografie są wzajemnymi komentarzami do siebie, bo w świecie twórczości tego artysty komentarz staje się literaturą, a literatura komentarzem ${ }^{15}$. To, co najważniejsze,

11 R. Nycz, Tekstowy świat. Poststrukturalizm a wiedza o literaturze, Universitas, Kraków 2000, s. 139.

12 Tamże, s. 145.

${ }^{13}$ H. Kajzar, Gwiazda, w: tegoż, Sztuki i eseje, Centralny Osrodek Metodyki Upowszechniania Kultury, Warszawa 1976, s. 126.

${ }^{14} \mathrm{~K}$. Taras, Witkacy i film, „Pamiętnik Literacki” XCIII, 2002, z. 4, s. 142.

15 I. Górska, O spotkaniach literatury $i$ komentarza $w$ twórczości Witkacego, „Przestrzenie Teorii" 2007, nr 7 . 
rozgrywa się $w$ dialogach - zarówno $w$ tekstach literackich, jak i teoretycznych. Odbicie Witkacego w jego tekstach przebiega na wielu poziomach - nie tylko pojawia się motyw zwierciadła umysłu, ale odpowiednia jest tu koncepcja autora jako sygnatury16:

Podmiot szkiców jest podmiotem ruchomym, zmiennym, niejednoznacznym; jest literatem, teoretykiem, uczestnikiem dyskusji, raz postacią fikcyjną, a raz sygnaturą samego Witkacego - autora teorii Czystej Formy ${ }^{17}$.

I choć cytowane rozważania dotyczą rozważań teoretycznych Witkacego, to mają swoje odbicie także w jego dramatach. Witkacowskie teksty to niekończące się odbicia, powielenia i refleksy.

Tekst bowiem nie jest stałym, raz danym zespołem znaczeń, lecz nieustannym procesem, „holograficzną mglawicą w przestrzeni semiotycznej”18.

Tę lustrzaną strukturę odbić oraz nakładania się i przenikania tożsamości realnych i fikcyjnych najlepiej oddaje fotografia artysty Portret wielokrotny $w$ lustrach ${ }^{19}$ (1915-1917). Witkiewicz sam siebie fotografuje stojącego tyłem do obiektywu a na wprost luster i odbijającą się w nich jego sylwetkę. Powielony jest czterokrotnie w swoich odbiciach, ukazujących go pod różnym kątem i dających w ten sposób wszechstronny ogląd jego ciała.

Lustrzaność i kolażowość tożsamości znajdują jedną z pierwszych realizacji, patrząc $\mathrm{z}$ dzisiejszej perspektywy badawczej, właśnie $\mathrm{w}$ twórczości Witkacego. Przykładem najbardziej wyrazistym jest $\mathrm{z}$ pewnością dramat $W$ malym dworku ${ }^{20}$. Widmo Matki jest postacią na poły ludzką, na poły z zaświatów. Choć porusza się sztywno, bardziej sunie nad powierzchnią ziemi niż po niej chodzi i przenika przez drzwi i ściany, to jednak podnosi przedmioty, pije kawę i wódkę, jej dotyk jest odczuwalny dla innych, dla wszystkich jest doskonale widoczna. Obraz jej osoby wyłania się z opowieści poszczególnych postaci, tworząc niejednoznaczny wizerunek. Anastazja nie może kłamać jako zjawa - mówi tylko prawdę, ale i tak jedynie na podstawie lustra własnej pamięci - ujawnia nieznane pozostałym fakty, ale poznaje ku własnemu zdziwieniu także ich wer-

16 Tamże, s. 110, 113.

17 Tamże, s. 110.

18 W. Kalaga, Mglawice dyskursu. Podmiot, tekst, interpretacja, Universitas, Krak6w 2001, s. 237-238; cyt. za: I. Górska, op. cit., s. 119.

19 S.I. Witkiewicz, Marginalia filozoficzne, teksty: B. Michalski, P. Polit, Katalog z wystawy w dniach 19 stycznia - 22 lutego 2004 r. w Centrum Sztuki Współczesnej Zamek Ujazdowski, redakcja katalogu P. Polit, Wydawnictwo Centrum Sztuki Współczesnej Zamek Ujazdowski, Warszawa 2004, s. 62-63.

${ }^{20}$ Witkiewicz Stanisław Ignacy, W malym dworku, Wydawnictwo Zielona Sowa, roku wydania nie podano, Kraków. 
sje. Widmo stanowi zatem odbicie człowieka takim, jakim był za życia, to refleks światła odbity na powierzchni lustra, który lada chwila zniknie; to etap przejściowy między dwoma światami. Widmami na ziemi zostają nazwani artyści. Rodzina - rodzice i dzieci - staje się spójną całością dopiero po śmierci, gdy wszyscy stają się widmami, choć bardziej widmowe wydaje się ich realne życie, a nie jako zjaw. Co więcej, założenia teoretyczne samego dramaturga znajdują swoje odbicie w słowach fikcyjnych postaci jego dramatu. Teoria estetyczna Witkacego zostaje włożona w usta stworzonych przez niego postaci i rozgrywa się w ich wypowiedziach, jest niejako „pisana na scenie”. Także jego lektury filozoficzne zostają wskazane wprost, wymienione z nazwisk ich autorów - Kant, Schopenhauer, Nietzsche, Russell - w wypowiedzi jednego z bohaterów, Kuzyna. Nie sposób jednoznacznie scharakteryzować tożsamości bohaterów tekstów Witkacego. Podobnie jak niemożliwe jest oddzielenie biografii, lektur i poglądów samego artysty od jego twórczości. Tożsamość dramatis personae znajduje odzwierciedlenie $\mathrm{w}$ światopoglądzie artysty. Tożsamość Witkiewicza zatem realizuje się rozbita na wiele świetlnych refleksów odbitych na powierzchni lustra jego tekstów.

Po zabieg lustrzano-świetlnych odbić sięgają, choć go oczywiście modyfikują dla własnych potrzeb, także Jean Genet i Samuel Beckett. Genet stosuje efekty błysku jako znaku przepychu (np. purpura i złoto królewskiego plaszcza w Balkonie), jak i tego, co odpychające i niesmaczne (połyskujący śliną pantofelek w Pokojówkach). U Becketta w świecie szarości światło odgrywa szczególnie ważną rolę, co przejawia się w stosowaniu przez niego szerokiego wachlarza światłocienia. Jego bohaterowie zamknięci są w przestrzeniach szarości, pogrążeni w półmroku. Swiatło tych przestrzeni jest trupioblade, matowe, odbarwione, nigdy nie ma w nim miejsca na lśnienie. Bohaterowie nie doznają iluminacji, ale tkwią w stanie przedśmiertnego półmroku, bladości czy raczej wyblakłości.

Świt jako stan przedświata, przedświetlny, niedoświetlony, przypomina pochłaniający promienie zmrok. Byt i niebyt mają swoje stadia pośrednie, przyglądają się sobie jak w lustrze ${ }^{21}$.

Szczególnie silnie efekt wygasania i zaciemniania widać w jego sztukach telewizyjnych.

Abrams posługuje się metaforą „zwierciadła i lampy”, analizując postrzeganie aktu twórczego w sztuce i literaturze epoki romantycznej i porównując ją $z$ wcześniejszymi poglądami ${ }^{22}$. W jego koncepcji umysł był zwierciadłem odbijającym światło rzeczywistości. Swiatło lampy od-

${ }^{21}$ A. Krajewska, Dramaty lustrzane, ed. cit., s. 404.

${ }_{22}$ M.H. Abrams, Zwierciadlo i lampa, tłum. M.B. Fedewicz, słowo / obraz terytoria, Gdańsk 2003. 
bitej w lustrze $z$ czasem zastępuje lśnienie emitowane przez ekran monitora. Ale tak naprawdę bardziej dominujące kategorie to ich przeciwieństwo - przygasanie i zaciemnianie ${ }^{23}$, zacienianie i znikanie.

W kręgu światła i lśnienia sytuują się także Baudrillardowskie rozważania dotyczące natury hologramu. Hologram to doskonałe złudzenie: ,jest rzutowany z przodu płytki fotograficznej w taki sposób, że nic nas od niego nie oddziela"24. Efekt foto- i kinematograficzny zastępuje holografia. Powołanie do życia tego świetlnego wynalazku doprowadziło do absolutnego podobieństwa, do swoistego klonowania obrazów, które zwiastuje koniec jakiegokolwiek złudzenia. To przejście na stronę sobowtóra, na drugą stronę własnego ciała, spotkanie ze swoim klonem utworzonym poprzez działanie światła. Laser jako wiązka światła pełni funkcję medium stwarzającego hologram.

Po fantazmacie ujrzenia samego siebie (zwierciadło, fotografia) nadchodzi fantazmat możliwości obejścia samego siebie, a w końcu i przede wszystkim, fantazmat przeniknięcia przez samego siebie, przejścia przez własne spektralne ciało [...]. W pewnym sensie jest to jednak koniec estetyki i triumf przekaźnika ${ }^{25}$.

W przypadku hologramu zabrakło możliwości lustrzanego dopełnienia i równoważności (ekwiwalencji) sensu, a w konsekwencji wyrugowano cień - tu rozumiany jako ukryta strona przedmiotu, która nie może znaleźć swojego odbicia - który jest naturalną konsekwencją padającego światła. Dominuje przejrzystość całkowitego rozświetlenia.

\section{Ani nie-ja, ani nikt inny ${ }^{26}$ - wobec fałszywego rozpoznania}

Jak postać ma określić siebie wobec lustra i ekranu? Przestrzeń lustra przyczynia się do wzmożenia w człowieku poczucia własnej odrębności fizycznej i psychicznej. Tu oczywiście od razu nasuwa się nawiązanie do teorii Lacana ${ }^{27}$. Mówił on o zjawisku Fazy Lustra, w której dziecko utożsamia się ze swoim obrazem, który znajduje w lustrze, gdyż daje mu

${ }^{23}$ A. Krajewska, Estetyka wspótczesnego dramatu, w: Teatr-media - kultura, pod red. D. Fox i E. Wąchockiej, Wydawnictwo Uniwersytetu Sląskiego, Katowice 2006, s. 65.

24 J. Baudrillard, Hologramy, w: Symulakry i symulacja, tłum. S. Królak, Wydawnictwo Sic!, Warszawa 2005, s. 131.

25 Tamże, s. 132.

${ }^{26} \mathrm{~S}$. Mrożek, Wyspa róż, w: tegoż, Utwory sceniczne nowe, Wydawnictwo Literackie, Kraków 1975.

27 K. Pawlak, Psychoanaliza wedlug Jacques'a Lacana, w: Nowe zjawiska w psychoterapii, pod red. M. Lis-Turlejskiej, Agencja Wydawnicza Jacek Santorski \& co, Warszawa 1991. 
poczucie całościowości lub spójności. Nie ma żadnego przeczucia osobnej tożsamości, która jest zawsze wyalienowana $w$ innym. To moment fałszywego rozpoznania, w którym obraz jest traktowany jako tożsamy z odbijanym, stojącym przed lustrem obiektem. Odróżnienie swojego odbicia od siebie realnego to już przejście od porządku wyobrażeniowego do porządku symbolicznego. Zatem w lustrze po raz pierwszy rozpoznajemy swoje ,ja" (jest ono także narzędziem ostatniego sprawdzianu oznak ludzkiego istnienia - oddech lub jego brak na przystawionym do ust lusterku). Problemem postaci dramatycznych i teatralnych najnowszych dramatów stających wobec lustra jest zatrzymanie się $w$ fazie utożsamienia i niemożność jakiegokolwiek przezwyciężenia tego impasu.

Lustra i ekrany (traktowane jako współczesne lustra) odsyłają do pola znaczeń związanego $\mathrm{z}$ grą między tym, co rzeczywiste, a tym, co pozorne; wprowadzają do świata dramatu i teatru grę odbić i zniekształceń rzeczywistości. Iluzja zaś ulega spotęgowaniu do poziomu symulakrum. Już samo tworzywo oraz dzieje lustra wskazują na jego miejsce między światem iluzji a światem realnym. W hinduskiej filozofii przeprowadzono analogię między jaźnią a odbiciem w lustrze lub w oku, a drogę prawdy nazywano Zwierciadłem Prawdy ${ }^{28}$. W średniowieczu pojmowano przedmioty widzialne, zarówno rzeczywiste, jak i przedstawione, jako znaki, symbole tego, co niewidzialne. Odbicie jest czymś pośledniejszym od przedmiotu odbijającego się. Zwierciadło przyczyniło się do wzmocnienia procesu poczucia własnej odrębności w sensie fizycznym i psychicznym $z$ jednej strony, a $z$ drugiej postawiło zasadnicze pytanie dotyczące jej podmiotowego statusu.

Wskazać można na wyraźny ciąg dramatów poruszających ten problem. Pojawienie się motywu gry lustrzanych odbić ma poważne konsekwencje dla formuly dramatu - wpisując się w jego linię rozwojową który można by nazwać postkartezjańskim. Po Do Damaszku Augusta Strindberga zmienia się wyraźnie widzenie dramatu - otwiera się nowy paradygmat. Samo określenie lustrzanych sztuk (the mirror-play) wprowadził Richard Begam ${ }^{29}$, wychodząc od twórczości Becketta, a zwłaszcza od jego sztuk telewizyjnych. Dramaty wpisujące się w ten ciąg na obszarze polskiej twórczości zaczynają się już od Witkacego, w którego dorobku najbardziej „lustrzane” wydają się Matka i Kurka Wodna oraz W maŁym dworku. Ogromne pole eksploracji otwiera twórczość Różewicza nie tylko zresztą dramatyczna. Pułapka, Do piachu, Białe małżeństwo to najwyrazistsze przykłady. Wśród dzieł europejskich, oprócz Becketta

$28 \mathrm{M}$. Wallis, Dzieje zwierciadta $i$ jego rola $w$ różnych dziedzinach kultury, Wydawnictwo Ossolineum, Łódí 1956, s. 30.

${ }^{29}$ R. Begam, Samuel Beckett and the End of Modernity, Stanford 1996. 
i Geneta, warto wymienić Rosencrantz $i$ Guildenstern nie żyja i Arkadię Toma Stopparda, Kaligule Alberta Camusa czy Gwiazdę Helmuta Kajzara.

Bohater jednego $\mathrm{z}$ nie najnowszego już dramatu, choć zaliczanego do współczesnej polskiej dramaturgii, Wyspy róż Sławomira Mrożka, stanowi doskonały przykład praktycznego rozpoznania czy może raczej nierozpoznania siebie w Fazie Lustra. To specyficzny typ dramatu, bo pełniący funkcję scenariusza filmowego z lat siedemdziesiątych, w którą wpisane są określone sposoby telewizyjnego (okiem kamery) obrazowania. Główny bohater, kilkunastoletni Chłopiec staje przed zadaniem przejścia od porządku wyobrażeniowego do symbolicznego $\mathrm{w}$ momencie spojrzenia po raz pierwszy w swoje lustrzane odbicie.

\section{OBRAZ 10}

Wymachując drewnianym wiadrem Chłopiec idzie ścieżką od zabudowań do cysterny. Ciemna powierzchnia wody w cysternie. Chłopiec klęka na cembrowinie, pochyla się nad wodą. W wodzie odbija się jego twarz jak w lustrze. Chłopiec przygląda się swojemu odbiciu. Wyciąga rękę, porusza palcami. Odkrywa, jak wiernie i równocześnie jego odbicie wykonuje te same ruchy. Wyciąga język, szarpie się za włosy, wykonuje rozmaite grymasy. Przestaje gestykulować i kontempluje swoje odbicie. Kamień pada w środek lustrzanego odbicia i roztrąca je koliście i faliście ${ }^{30}$.

Rozpoznanie takie powinno nastąpić, jak pisze Lacan, między szóstym a osiemnastym miesiącem życia. Chłopiec jednak żyje w takiej izolacji, tak że proces ten zostaje przesunięty w czasie. Gdy wreszcie rozpoznaje siebie $\mathrm{w}$ lustrzanym odbiciu i ma szansę się $\mathrm{z}$ nim utożsamić, wydaje się, że nie jest zdolny do końca tego dokonać. Na chwilę myśli o sobie jako o ,ja”. Rozpoznaje swoje ciało, czyli ego cielesne.

Należy jednak pamiętać, że nie chodzi tu o ciało „rzeczywiste” czy „naturalne”, a ciało wyobrażone przez innego/innych - o lustrzany obraz ciała. Lacan na określenie owego ciała wprowadza termin „anatomia wyobrażeniowa”31.

Chłopcu udaje się rozpoznać siebie dzięki pojawieniu się na wyspie Kobiety. Dopiero dzięki niej zaczyna dostrzegać siebie w sensie płciowym - najpierw mial przybranego Ojca - Starca, a dopiero później pojawia się symboliczna Matka - jako nie posiadająca fallusa. Proces rozpoznania jest więc u niego od początku zaburzony. Dopóki nie pojawia się Kobieta, nie zajmuje ani pozycji „męskiej”, ani „kobiecej”, gdyż nie zna tego rozróżnienia.

${ }^{30} \mathrm{~S}$. Mrożek, op. cit., s. 148.

${ }^{31}$ A. Jakubowska, Na marginesach lustra. Ciato kobiece $w$ pracach polskich artystek, Universitas, Kraków 2004, s. 24. 
Inicjacja Chłopca odbywa się, kiedy Kobieta wtajemnicza go w końcu w arkana męskiej seksualności. Najpierw widzi Kobietę opalającą się nago na plaży - jest jednak na tyle daleko od niego, że nie dostrzega wyraźnie szczegółów jej kobiecej anatomii. Rozpoznaje w końcu siebie, swoją tożsamość - ale jest to dla niego tak trudne, że ledwo jest w stanie ten fakt pojąć. W kluczowej scenie dostrzega swoje odbicie w lusterku, które Kobieta wyjmuje ze swojej torby.

Chtopiec wyciqga rękę po lusterko. Przyglqda się sobie w lusterku.

CHŁOPIEC: To jestem ja?

KOBIETA: Oczywiście. Ty, wyłącznie ty.

CHŁOPIEC: Co to znaczy ,ja”?

KOBIETA: To znaczy, że ani nie ja, ani nikt inny ${ }^{32}$.

Wydaje się, że dokonuje rozpoznania opartego na sylogistycznym wnioskowaniu ${ }^{33}$ - skoro widzi odbicie twarzy, a tylko on stoi przed lusterkiem, to musi być jego odbicie. Jednak chlopiec nigdy nie opuszcza wyspy, klasztoru, przybranego ojca. Wraca do poprzedniego stanu nierozpoznania, czego symbolicznym gestem staje się zatopienie Kobiety razem $z$ jej łodzią i sprzętem - radiowym, fotograficznym, filmowym i elektroakustycznym, za pomocą którego podglądała życie na wyspie, oraz wrzucenie do wody kamyka w sam środek własnego odbicia, który je zakłóca i rozprasza.

Jednocześnie wszyscy trzej mieszkańcy klasztoru położonego na wyspie otoczonej morzem, Chłopiec, Mężczyzna i Starzec, dokonują prób rozpoznania. Chłopiec, jak już powyżej zostało pokazane, próbuje przejść w etap dorosłości. Mężczyzna szuka siebie sprzed piętnastu lat w lustrze fotografii. Ogląda stare zdjęcia siebie niepodobnym do siebie teraz, szukając jakiegoś sensu swojej obecnej egzystencji. Nie potrafi jednak scalić obrazu siebie ze szczątków przeszłości. W scenach z fotografiami widać ciekawą grę między wielością w jedności a jednością w wielości. Na zdjęciach ogląda obrazy mężczyzn - robotników i marynarzy - na tle portowej przystani, pośród których widoczny jest młody człowiek bez zarostu, jego obraz z młodości. Na pozostałych fotografiach ogląda wizerunek tego samego młodego mężczyzny, siebie sprzed wielu lat, w mundurze marynarki wojennej oraz dziewczynę w kostiumie kąpielowym pozującą na tle morza - niechybnie dawną ukochaną. Nie chcąc dokonać rozpoznania siebie w lustrze przeszlości, drze fotografie, choć później próbuje ich strzępki złożyć z powrotem w całość. I wtedy zdarza się coś dziwnego przeszłość sama upomina się o niego:

32 Tamże, s. 179-180.

${ }^{33}$ Arystoteles, op. cit. 
W kręgu lampy leżą na stole trzy fotografie, nietknięte, jakby nigdy nie zostały podarte albo jakby zrosły się z powrotem w magiczny sposób ${ }^{34}$.

Tęskni za przeszłością, ale fotografie są dla niego swego rodzaju wentylem bezpieczeństwa - traktuje je jak sztuczne obrazki. Patrząc na zdjęcia, zastępuje sobie obraz kobiet, których na co dzień nie widuje i przed którymi stara się uciec. Fotografia dziewczyny sprzed lat zostaje skonfrontowana ze zdjęciami, które Kobieta mu podrzuca - pornograficznymi, brutalnie obnażającymi jej życie seksualne. Od tych zdjęć również się odwraca. Niszczy nawet aparat fotograficzny Kobiety - nie chce rozpoznania.

Starzec natomiast dokonuje oglądu i poznania przestrzeni wokół klasztoru. Jest tak zniedołężniały, że jedynie obserwowanie przez lunetę otoczenia daje mu obraz tego, co się wokół niego dzieje. Wykadrowane fragmenty to jednak jedynie namiastka rzeczywistości, jej wyabstrahowane wycinki, które nie przynoszą właściwego rozpoznania. W przypadku Starca kontakt ze światem zewnętrznym ogranicza się do obserwacji go przez lunetę, czyli ma charakter zapośredniczony.

Bohaterowie pozostają w zamknięciu niewiedzy, odrzucenia lustrzanego odbicia - momentu identyfikacji, kontaktu $z$ ego własnej tożsamości. Motyw pojawiającej się na wyspie Kobiety, wprowadzającej w życiu trojga jej mieszkańców tożsamościowe zamieszanie, nasuwa skojarzenia $\mathrm{z}$ jedną z Freudowskich koncepcji. Badacz utrzymywał, że mężczyzna przez całe życie poszukuje kobiety, która będzie taka jak jego matka będzie jej lustrzanym odbiciem. Chłopiec nie znał swojej matki, Mężczyzna traci wyidealizowany obraz „tej” kobiety w konfrontacji z jej „niemoralnymi" zdjęciami, Starzec dobrowolnie wyrzeka się kobiecego towarzystwa, wybierając życie mnicha. Bohaterowie zaspokajają jedynie dwie z podstawowych potrzeb, o których pisze Freud jako o podstawowych jedzenia i ciepła. Seks pojawia się na moment za sprawą Kobiety, ale świadomie go odrzucają, usuwając ją z wyspy i niszcząc jej narzędzia obserwacji oraz wykonane przez nią zdjęcia i nagrania. Pozostają w pułapce-schronieniu, którą sami sobie stwarzają.

Podobną sytuację gry między ty i ja, szukaniem własnej tożsamości i rozpoznania, przedstawia Gombrowicz w swoich dramatach (zresztą cała jego twórczość oscyluje wokół tego problemu). Pisarz nie traktuje literatury jako „tylko lustra”, ale podejmuje złożoną grę z czytelnikiem.

Literatura mogłaby być po prostu „lustrem”, gdyby coś odbijała: zobiektywizowaną osobowość swego twórcy. [...] Gombrowicz kimś być nie chce, musi więc

${ }^{34}$ S. Mrożek, op. cit., s. 166. 
czytelnikowi zaproponować inną grę - już nie w odczytywanie prawdy o autorze $\mathrm{z}$ jego dzieła, lecz w uczestnictwo w autokreacyjnym procesie ${ }^{35}$.

„Ja" autorskie zostaje rozbite na wielogłos jego tekstów i postaci. Ukazuje kryzys ,ja” w wydaniu Foucaulta, Deleuze'a czy Derridy. Jego bohaterowie bronią zaciekle suwerenności swojego ego, zatrzymując się na poziomie zaspokajania przede wszystkim erotycznych popędów. Ślub jest kwintesencją tej problematyki. Henryk śni, a wszystko, co się wydarza, jest „rozpisaniem na role jego wewnętrznych konfliktów, kompleksów, niskich namiętności"36. Pijak odgrywa rolę alter ego bohatera, jego swego rodzaju „negatywu”37. A Władzio, ostatnia nić łączności ze światem zewnętrznym, zabija się na wyraźną prośbę samego Henryka. Bohater nie potrafi poznać natury ani naznaczyć granic swojego ,ja” - tkwi w nierozpoznaniu, oscyluje między ,ja” i „nie-ja”, mimo nieustannych prób samookreślenia. Także Operetka to swoista "garderoba duszy"38. Bohaterowie uciekają tu przed własnym ,ja”, przywdziewają maski i kostiumy strojów. Próbują przebić się do Innych, pokonać zasłonę konwenansu - bezskutecznie. Albertynka jest tu jeszcze „powiewem nadziei” rozpoznania siebie we własnej nagości i erotyzmie. Ale wśród tych postaci coraz więcej jest „cierpiących monad, płacących zbyt drogo za upragnione wyjście ku Innemu”39.

W jednym $\mathrm{z}$ najnowszych tekstów młodej polskiej dramaturgii, które kontynuują i przekształcają wątki klasycznych twórców, w dramacie Zastępstwo ${ }^{40}$ Małgorzaty Owsiany głównym elementem scenografii jest trzydrzwiowa szafa $z$ przesuwanymi drzwiami. Jedno jej skrzydło jest lustrzane. Lustro to wielokrotnie jest czyszczone i polerowane. Odbija pokój - jak zauważa Henryk. Przed nim ubiera się, zanim wyjdzie do pracy czy na oficjalną kolację i ocenia swój wygląd, w nim przegląda się Ludmiła, szukając $\mathrm{w}$ sobie resztek urody. Zauroczona nowym listonoszem, zmęczona dotychczasową monotonią, dręczona wspomnieniami zaprzepaszczonej miłości, w lustrze szuka siebie - poprzez nie próbuje skomunikować się ze swoim wnętrzem, odnaleźć prawdę o sobie. Odbicie traktuje jako równie rzeczywiste jak ona sama. Lustro staje się narzędziem komunikacji bohaterki z jej drugim ja - wewnętrznym, zbuntowanym głosem. Zarazem miejscem zaistnienia jej wyobrażeń i marzeń,

35 J. Jarzębski, Podglqqdanie Gombrowicza, Wydawnictwo Literackie, Kraków 2000, s. 19.

36 Tamże, s. 102.

37 Określenie za: tamże, s. 104.

38 Określenie za: tamże, s. 106.

39 Określenie za: tamże, s. 120.

${ }_{40}$ M. Owsiany, Zastępstwo, www.tat.pl. 
których nigdy nie odważa się zrealizować. Staje się znakiem jej tożsamościowego rozdwojenia.

W spektaklu w reżyserii współczesnej, początkującej inscenizatorki Moniki Pęcikiewicz Twój, twoja, twoje (w Teatrze Polskim w Poznaniu, premiera: luty 2006 r.) pojawia się znamienna scena Iona i Noi - ich imiona to odbicia lustrzane. To nie dwie oddzielne postacie, ale grana przez dwójkę aktorów jedna „hermafrodytalna” postać - gdy przegląda się w lustrze na końcu tej sceny, to mimo męskiego ciała Iona widzimy w nim kobiecą twarz - twarz Noi. Przywodzi to na myśl mityczną postać dwupłciową - Hermafrodytę, syna Hermesa i Afrodyty, z którym zrosła się za sprawą bogów zakochana w nim Nimfa:

Tak ich członki w uścisku się zrosły, już nie ma dwojga, lecz podwójne ciało, trudno powiedzieć, czy kobieta czy mężczyzna, nijakie a podwójne ${ }^{41}$.

\section{W sieci kolażowych tożsamości - wobec niemożliwej integracji}

Tożsamość członków dzisiejszej komunikacji staje się tożsamością płynną, jak ją nazywa Berger ${ }^{42}$, rheomorficzną - tożsamość taka podlega ciągłemu rozkładowi na skutek pojawiających się nieustannie komunikatów medialnych. W lustrzanomultimedialnym spektaklu mnożą się odbicia, rzeczywistość sceniczna jest oparta na symulacji. Przedstawiany świat oscyluje między realnością a lustrzano-ekranową iluzją, pozorem, kopią, symulakrum. Widzialność stała się obiektem nadzoru, bohaterowie tych dramatów zostają schwytani w pułapkę widzialności, poddani są nieustannej kontroli i dyscyplinowaniu. Benthamowski panoptikon opisany przez Michela Foucaulta ${ }^{43}$ to jedyna realność, jaką znają. Nie „żyją", ale „tkwią" uwięzieni w lustrzanej przestrzeni domu publicznego, internetowego czatu, gier komputerowych czy filmowej projekcji. Gra spojrzeń, poddanie wizualnej kontroli staje się narzędziem samokontroli i samoujarzmienia. Nieustanne umieszczenie w polu widzialności sprawia, że nigdy nie przestają się kontrolować, nie wychodzą poza pozór,

41 Owidiusz, Metamorfozy, przekład i wstęp S. Stabryła, Wydawnictwo Ossolineum, Wrocław-Warszawa-Kraków 1995, s. 101, cyt. za: A. Jakubowska, Na marginesach lustra. Ciato kobiece w pracach polskich artystek, Universitas, Kraków 2004, s. 35.

42 R. Berger, Od telewizji-żywicielki do telewizji-matki, "Kultura Współczesna" 2006, nr 3 (21), s. 21-27.

${ }^{43}$ M. Foucault, Nadzorować i karać. Narodziny więzienia, przeł. i posłowiem opatrzył T. Komendant, Wydawnictwo Aletheia-Spacja, Warszawa 1993. 
w którym tkwią. Mimesis to tylko naśladowanie symulakrów, pusty zabieg, który niczego już nie odzwierciedla poza iluzją, stając się iluzją iluzji.

Ekran, choć to medium dużo nowsze i pozornie o zgoła odmiennej strukturze materialnej, to jednak stosowany jest współcześnie w kontekście poszukiwań tożsamościowych $\mathrm{w}$ podobnej funkcji jak lustro. Obraz na ekranie powstaje na skutek działania światła. Tak było w przypadku pierwszych fotografii, filmu kinowego, jak i różnorakich projekcji. Monitor działa w drugą stronę - emanując światło, wytwarza obraz. Ta właściwość poszerza możliwości zaistnienia obrazu, otwierając przy tym szerokie pole możliwości jego manipulacji, zniekształceń i innych iluzyjnych zabiegów. Era lustra przekształca się stopniowo w erę ekranu. Choć oko kamery można traktować jako współczesne zwierciadło, to jednak zaszły tu znaczące różnice. Lustro nie zatrzymuje obrazu, nie ma zdolności zmieniania planów, kadrowania $z$ wielu różnych perspektyw, nie potrafi utrwalać odbicia. Zwierciadło daje pewne poczucie bezkarności - obraz w nim pojawia się jedynie na chwilę, żeby zaraz zniknąć. Kamera utrwala, zatem zostawia ślad przeszłości. Żyjąc w świecie ciągłej widzialności, bohaterowie znikają, bo realne ich postaci zostały zastąpione przez przedstawienie, a przedstawienie przez swój odblask, a ten odblask przez kolejny odblask ${ }^{44}$.

Poznanie poszerza się i zawęża jednocześnie poprzez obecność luster i ekranów. Poznanie dramatyczne jest bardzo specyficzne i silnie wpisuje się w metaforę lustra i ekranu. Jak pisze Anna Krajewska,

poznanie przez dramat łączy w sobie poznanie literackie ze specyficzną projekcją (projektem?) doznania zmyslowego (patrzenie jako typ poznawczego doświadczenia $\mathrm{i}$ analizowania świata wpisane jest $\mathrm{w}$ reguły dramatu poprzez jego związek $\mathrm{z}$ nastawieniem na wykonanie, najczęściej teatralne). [...] Teatr, oznaczając świat, kwestionuje jego istnienie, umieszczony między ekranem a rzeczywistością - rozgrywa się w istocie jakby po drugiej stronie lustra. Nie między okiem a rzeczą, lecz między okiem - sceną (ekranem), lustrem a rzeczą ${ }^{45}$.

Dominującymi kategoriami opisu stają się estetyka śladu, rozsunięcia, recyclingu ${ }^{46}$, montażu, fragmentu, powtórzenia. Te estetyki wpisują się w szersze zjawisko, które zostaje tu nazwane estetyką luster i ekranów. Kategorie te świetnie służą opisowi świata wewnętrznego, przeżyć psychicznych i emocjonalnych, rozbicia tożsamości i osobowości człowieka we współczesnym świecie.

${ }_{44}$ Pojęcie odblasku za: A. Falkiewicz, Wstęp, w: J. Genet, Teatr, przeł. J. Błoński, J. Lisowski, M. Skibniewska, Państwowy Instytut Wydawniczy, Warszawa 1970, s. 35-38.

${ }^{45}$ A. Krajew ska, Estetyka wspólczesnego dramatu, s. 51.

46 Określenia estetyki śladu, estetyki rozsunięcia i estetyka recyclingu za: A. Krajewska, Estetyka wspólczesnego dramatu, s. 52-53. 
Na występowanie takich ekranów w teatrze Tadeusza Różewicza zwraca uwage Ewa Wąchocka:

ze względu na wyraźnie pozasłowny charakter narracji można też odwołać się do metafory ekranu, gdyż na podobieństwo ekranowego rzutowania i odwzorowania stają się one [obrazy-sny, obrazy-asocjacjel domeną widzialności ${ }^{47}$.

Przez ekran odzywa się zatem ego człowieka, które może odgrywać rolę negatywną. Jung uznał, iż dzieje się to w przypadku, gdy stłumione są pozytywne cechy osobowości. Projekcje są bowiem tak mocne, że jednostka nie może w żaden sposób ich przebić - to one są dla niego rzeczywistością. Jego działania nie są oceniane, tzn. on nie ocenia ich w żaden sposób jako nagannych moralnie ${ }^{48}$. Cień - u Junga jako problem moralny - ma wpływ na całą ego-osobowość. Podstawą samopoznania w takim ujęciu staje się uznanie własnych negatywnych cech - jest to akt nieodzowny i spotykający się $\mathrm{z}$ wielkim oporem. Trudno jest przyznać przed samym sobą, że popełniło się czyn negatywny moralnie i że dokonało się tego właśnie ze względu na istnienie jakiś projekcji w naszym umyśle. Projekcja - ekran wypełnia nasz umysł w stosunku do danej sytuacji, nasze działanie jest nim spowodowane, popełniamy jakieś przewinienie, bo wydaje się nam ono co najmniej neutralne moralnie. Tym, do czego tak trudno nam się przyznać, jest ten opór. Dopiero po jego przełamaniu dokonujemy samopoznania ${ }^{49}$. A zatem $w$ lustrzanym odbiciu widzimy swoje najciemniejsze strony rzutowane $\mathrm{z}$ "cienia" na tę gładką powierzchnię. Bohaterowie wielu współczesnych dramatów tego samopoznania nigdy jednak nie doznają.

Ekran kamery jako narzędzie kształtowania człowieka - jego wizerunku oraz rejestracji zachodzących $w$ nim przemian, także tych tożsamościowych, pojawia się w sztuce Ksztalt rzeczy Neila LaBute'a ${ }^{50}$. Tak jak lustro jest świadkiem ludzkich przemian, które dokonują się za sprawą stroju, gestów, mimiki, tak i ekran pełni tę funkcję. Nie ogranicza się on do roli świadka - ma bowiem dodatkowo moc utrwalania oraz stwarzania, preparowania iluzji poprzez zabiegi montażu, filmowych trików aż po efekty specjalne tworzone techniką cyfrową. Nagrane na kasetę wideo sceny intymne między parą bohaterów tracą, poprzez fakt

${ }^{47}$ E. Wąchocka, Ekrany świadomości w teatrze Tadeusza Różewicza, w: Wiek ekranów. Przestrzenie kultury widzenia, pod red. A. Gwoździa i P. Zawojskiego, Wydawnictwo Rabid, Kraków 2002, s. 216.

48 C.G. Jung, Archetypy $i$ symbole. Pisma wybrane, wybór, przel. i wstęp J. Prokopiuk, Czytelnik, Warszawa 1993, s. 68.

49 Tamże, s. 69.

${ }^{50}$ N. LaBute, Ksztalt rzeczy, przeł. M. Semil, Spektakl na podstawie tekstu dramatu - reż. B. Wyszomirski, premiera: 21.10.2005, Teatr Miejski w Gdyni, „Dialog” 2002, nr 3 . 
filmowania kamerą, całą swoją intymność. Dodatkowo ujawnienie kaset i zarejestrowanych na nich obrazów na forum publicznym - to akt skrajnego ekshibicjonizmu. Evelyn z Adama uczyniła „żywą rzeźbę", zmieniając całkowicie jego wizerunek i osobowość, aby następnie przedstawić (wystawić) go jako element wystawy - prezentacji swojej pracy dyplomowej. Ekran jako kamera chroni przeszłość przed zapomnieniem, utrwalając jej najwspanialsze momenty. Jednocześnie zarejestrowane obrazy są murem odgradzającym bohaterów od samych siebie, od prawdy rzeczywistości. Evelyn nie była autentyczna w swoich doznaniach, udawała uczucia w ramach przeprowadzanych badan naukowych. Wybrany chłopak stał się obiektem eksperymentu w ramach jej projektu, polegającego na ukształtowaniu wyglądu i charakteru człowieka według określonego wzorca. Jednak zarejestrowane obrazy przekazują nienaruszoną iluzję doznań, nadając im znamiona prawdy, ale tylko w medialnym przekazie. I ten fakt utrwalenia to zasadnicza różnica między lustrem a ekranem - iluzoryczna natura obrazu zostaje spotęgowana i utrwalona. Bohaterowie, zamknięci w iluzji zbudowanej na kłamstwie, nie odróżniają już światów fikcyjnych od realnych. Zatracają własną tożsamość. Jednocześnie Adam widzi siebie w oczach Evelyn i w oku jej kamery, a zatem w oczach Innego. Wkracza tu koncepcja ja jako kogoś innego, rozgrywająca się na poziomie gry spojrzeń. Bohater zyskuje medialną tożsamość, w ramach większej całości tożsamości kulturowej. Jednak ta medialna jest tak silna, rozrośnięta czy wręcz przerośnięta, że zyskuje dominację nad kulturową, stając się jej jedyną wszechogarniającą częścią.

Twórcy teatralni dostrzegają w ekranach, oprócz ich aspektu scenograficznego, nadającemu spektaklom rys współczesności, także ich szczególną funkcję semiotyczną. A idąc jeszcze dalej - funkcję performatywną, czyli prowokującą działanie, stwarzaną w sugestiach, rozrywającą, fragmentaryzującą i zderzającą elementy dramatyczne. Bohaterowie ich sztuk nie potrafią się już przeglądać w lustrach, w ich domach nawet nie ma luster, bo nie ma potrzeby ich posiadania; przeglądają się za to w ekranowych wizerunkach (które przybierają dla nich status lustrzanych odbić) bohaterów audiowizualnej kultury, kształtując swoje życie na ich wzór. Chłopiec w dramacie Sierota Andrzeja Pieczyńskiego chciałby być tytułowym sierotą z gry komputerowej, której kolejne poziomy pokonuje, pragnąc znaleźć swojemu bohaterowi właściwą rodzinę, która go zaadoptuje. Ekran komputera, na którym rozgrywa się akcja tejże gry, to lustro, w którym odbija się prawdopodobny przyszły los Chłopca. Jego matka umiera na raka, a ojciec wyjechał wiele lat temu do Niemiec i nie ma ani ochoty, ani czasu na podjęcie opieki nad synem. Chłopiec zatem, grając na komputerze w swoją ulubioną grę - w szukanie domu 
idealnego, chroni siebie samego przed straszną prawdą o grożącym mu sieroctwie.

Skrajnie zapośredniczone relacje między postaciami zarysowuje $\mathrm{Pa}$ weł Jurek w dramacie $x 2$ [Wstyd / Bezwstyd] ${ }^{51}$. Telewizor, kaseta wideo - to rekwizyty, które urastają do rangi symboli i metafor medialnego przekazu, a nawet zyskują status głównych elementów warunkujących i kształtujących tożsamość postaci. Hamlet był już Hamnetem ${ }^{52} \mathrm{w}$ internetowej realizacji, a w dramacie Jurka staje się „Hamletem” porno. W swojej scenicznej realizacji zyskuje formę zbliżoną do peep-show, którego widzami staje się teatralna publiczność. Telewizor i program z niego emitowany pełnią funkcję nie tylko tła akcji. W pierwszym akcie na ekranie emitowany jest talk-show, w którym ludzie okładają się po głowach, i reklamy, których uzupełnieniem jest dodatkowo przeglądany przez bohatera nazwanego 30 dziennik-tabloid „Fakt”. Brukowiec staje się źródłem informacji o postaci nazwanej 60 - punktem zwrotnym dla Reżysera poszukującego aktora do swojego projektu teatralnego. Zobaczył bowiem na okładce tabloidu zdjęcie 60 , który idealnie pasuje do jego wizji artystycznej, wedle której Hamlet ma być stary i zniszczony. Zastosowany tu chwyt sięga do tradycji chwytu teatru w teatrze, a zwłaszcza do pirandellizmu.

60 poprzez brak współpracy ze światem mediów - odmowę grania w reklamach, serialach i występowania w talk-show, został wykluczony ze świata aktorskiego; nie chce i nie potrafi komunikować się z nową medialną rzeczywistością i posługiwać się jej językiem. Ale Hamlet staje się właśnie tworem złożonym z „medialnej papki”, bo tylko takiego jest w stanie zrozumieć współczesny widz. Nagranie wideo Hamlet porno, kupione w sex-shopie, staje się inspiracją do powstania spektaklu. Jednak na ekranie zamiast pornografii pojawią się jakieś wstępne rozmowy. Zatem komunikat słowny jest rozbieżny $\mathrm{z}$ komunikatem wizualnym, a percepcja bohatera, który widział na tej kasecie realizację porno, jest wobec tych faktów głęboko zaburzona. W świecie zdominowanym przez medialną komunikację „Hamlet siądzie przed telewizorem... Będzie patrzył zafascynowany [...] A potem ... Potem będzie się... [...] Będzie się onanizował" 53 . Całą komunikację między aktorami grającymi postaci na scenie zastępuje telewizor, któremu partneruje 60 . Telewizyjne obrazy stają się integralną częścią odgrywanej przez niego postaci.

${ }^{51}$ P. Jurek, x2 [Wstyd / Bezwstyd], www.tat.pl.

52 Spektakl Hamnet opisuje T. Kubikowski, Teatr $w$ sieci, w: Kultura $i$ sztuka u progu $X X I$ wieku, Seria Kultura i przyszłość, red. S. Krzemień-Ojak, wspólpraca red. A. Kisielewska, Z. Suszczyński, Trans Humana, Białystok 1997.

${ }^{53}$ P. Jurek, op. cit. 
W drugim akcie pojawia się w zamyśle reżysera wizja Hamleta jako serialu telewizyjnego. Dwór, czyli wszystkie postacie odgrywane są przez aktorów $\mathrm{w}$ foyer i mają być obserwowane za pomocą kamer telewizyjnych. A Hamlet ma dialogować z obrazem przesyłanym z kamer do telewizora - jedynym elementem scenografii i rekwizytem obecnym na scenie. Przepustką do roli teatralnej staje się rola telewizyjna w serialu Kochana rodzinka oraz nagroda Telekamery. Taki aktor staje się darmową reklamą dla przedstawienia jako Janek z serialu. Formy medialnej kreacji stają się ważniejsze od aktorskich umiejętności i ambicji zawodowych bohatera. Aktor nie chce jednak być Jankiem z serialu ani serialowym Hamletem, ale tylko aktorem. Nie chce, żeby ludzie przychodzili do teatru obejrzeć Janka $\mathrm{z}$ serialu. Ale nad tym procesem identyfikacji nie jest $\mathrm{w}$ stanie zapanować. To powolny proces zacierania $\mathrm{i}$ tworzenia kolażowej tożsamości medialnej.

Dramatopisarz wykorzystuje także efekt lustrzanego odwrócenia ról, pokazujący wymianę wewnętrznych przestrzeni - światów bohaterów, odwracając między aktami role osób dramatu. W pierwszej części występuje 60 - Aktor i 30 - Reżyser, a w drugiej 60 - Reżyser i 30 - Aktor. 60 jako aktor jest 60-letnim przegranym alkoholikiem. W miare rozwoju akcji zostają ujawnione ich imiona - 30 to Paweł, 60 to Adam. 60 ma 60 lat, jest zniszczonym, zaniedbanym człowiekiem w poszarpanym ubraniu, z butelką alkoholu w ręce. Za to 30 jako Reżyser jest jego przeciwieństwem - ma 30 lat, ale wygląda na młodszego dzięki modnym ubraniom i fryzurze, w jednej ręce trzyma telefon komórkowy, w drugiej hamburgera. W drugiej części dramatu następuje odwrócenie ról między reżyserem i aktorem - niczym w lustrze $z$ lunaparku, które odwraca i zniekształca. 60 jest Reżyserem, ma 60 lat, jest ubrany jak typowy inteligent. 30 to Aktor, ma 30 lat, choć wygląda na mniej, ma na sobie dżinsy i t-shirt oraz niedbałą fryzurę. Jest popularnym aktorem telewizyjnym, a chciałby grać „wielkie role”. 30 nadal ma na imię Paweł. Jednak Adam, podany tu $w$ rozmowie $z$ nazwiska jako Adam Potocki, nie może być już utożsamiany z 60 . Sprawa się komplikuje, gdy 30 okazuje się niespełnionym reżyserem, który wystawiał Hamleta z udziałem Adama - ma więc pewne elementy życiorysu Reżysera z pierwszej części sztuki. 60 jako Aktor grał właśnie grabarza w tym offowym teatrze. I w końcu obaj aktorzy, i ten 60-letni, i ten 30-letni buntują się przeciwko przedstawieniu, w którym ich obsadzono, a które nie zgadza się z ich wizją teatru.

60 podchodzi do telewizora. Patrzy na niego, jakby widzial go po raz pierwszy $w \dot{z} y c i u$. 
Odwraca sie do telewizora. Zdejmuje spodnie. Pokazuje goty tyłek. Zapina spodnie. Odchodzi. [...] $]^{54}$

Analogicznie postępuje $30 \mathrm{w}$ II akcie dramatu, przeradzając przedstawienie $\mathrm{w}$ spektakl konsumpcji. 30 kopie telewizor i $\mathrm{z}$ hollywoodzkim uśmiechem przemawia do publiczności:

30: To ja... Hamlet... Nie, Janek... Co ja mówię, na imię mam przecież Paweł... Przyszedłem tutaj, bo chciałem zaprosić państwa do mojej pizzerii. Nazywa się Teatr To My... O pardon!

Poprawia się.

30: Pizza To My!

Wyjmuje z kieszeni ulotki reklamowe i rozdaje je widowni ${ }^{55}$.

Młodość i starość, tradycja i ponowoczesność, role aktora i reżysera, sposób odrzucenia przez bohaterów nieakceptowanych modeli rzeczywistości odbijają się jak w krzywym zwierciadle, komplikują i naświetlają nawzajem między pierwszą a drugą częścią tekstu Jurka.

Lustrzane i ekranowe odbicia stają się autonomicznymi bytami, które nie tyle współtworzą świadomość postaci, ile ją przerastają. Kod zwierciadlany wprowadzony przez Jeana Altera

Działa [...] tak, jak zwierciadło w drugim tomie przygód Alicji - odbicia to nie fantomy, lecz istoty $\mathrm{z}$ krwi i kości ${ }^{56}$.

Aktor, który gra rolę Hamleta, nie staje się nim w tradycyjnym rozumieniu. Między aktorem a postacią literacką ustawione jest lustro. Ale gdy ustawimy ekran, to może dojść do ich utożsamienia. Symulacja staje się autentycznym doznawaniem. U Jurka postać aktora odrzuca tożsamość swojej postaci, ale jego widzowie, jak i reżyser spektaklu widzą w nim aktora-postać. Także postacie mogą zakłócać proces lustrzanego odbicia rzeczywistości $\mathrm{w}$ teatrze, dyskutując na przykład $\mathrm{z}$ poglądami autora, jak to ma miejsce w sztukach Witkacego lub mając pełną świadomość swojej fikcyjności, domagać się własnej autonomii i własnej historii (wystarczy przywołać zjawisko pirandellizmu i wzorcowego dramatu Sześć postaci $w$ poszukiwaniu autora, gdzie fikcyjna rodzina bohaterów literackich przybywa do teatru, by odnaleźć dramaturga, który

54 Tamże.

55 Tamże.

56 J. Alter, A Sociosemiotic Theory of Theater, University of Pensylvania Press, Philadelphia 1990, cyt. za: G. Sinko, Dzieto czy proces? Literatura - scena - krytyka, w: Od dokumentacji do interpretacji, od interpretacji do teorii: wybór materiatów $z$ Sesji Komitetu Nauk o Sztuce Polskiej Akademii Nauk, Nieborów 9.-11.10.1991 r., pod red. D. Kuźnickiej i H. Samsonowicz, Instytut Sztuki Polskiej Akademii Nauk, Warszawa 1998 , s. 61. 
mógłby opisać ich historię, której fabułę noszą gotową w sobie). Zjawisko teatru w teatrze to również realizacja efektu lustrzaności.

Omówiony dramat przywołuje także niezmiernie ważny kontekst - szekspirowski dramat, który odsyła do rozpatrywania twórczości teatralnej jako zwierciadła. Teatr przecież od czasów starożytnych, od Szekspira czy Racine'a, próbuje postawić nas przed lustrem, konfrontując z tym, co ukryte i podświadome. Auden, zainspirowany Burzq Szekspira, zauważył w swoim eseistycznym komentarzu, że aktorzy w zwierciadłach swoich gestów i zachowań odbijają na scenie rzeczywistość. A sztuki Szekspira są najdoskonalszą tej idei realizacją. Efekt zwierciadła jest konstrukcyjną zasadą wielu scen i wątków dramatu. Ariel jest echem, rodzajem zwierciadła, w którym odbijają się słowa Prospera, a w lustrze jego oczu

Wszystko, czym nie jesteśmy, odwzajemni spojrzenie temu,

Czym jesteśmy ${ }^{57}$.

$\mathrm{Z}$ jednej strony lepiej widzieć obrazy świata poprzez lustra teatru niż bezpośrednio, bo tylko takie spojrzenie umożliwia dystans do świata i samego siebie i pełne zrozumienie przekazywanych treści. Ale takie zapośredniczone spojrzenie niesie ze sobą ryzyko zniekształcenia. Prawdę można znaleźć w przestrzeni snu, który stanowi ciemność, mglistość zdradzającą prawdziwe oblicze postaci. Zdobne zwierciadto jedynie oślepia swoim lśnieniem.

Problemy z podmiotowością i rozpoznaniem własnego ,ja”, według Audena, znajdują swoją realizację zarówno na poziomie aktor - rola, jak i samych postaci - bohaterów Burzy. Cala rzeczywistość dramatu jest teatralną grą postaci, operq graną w mózgu poszczególnych bohaterów. Ariel spoglądający $z$ powierzchni lustra jest posłusznym rozkazom duszkiem, ale spotkanie $\mathrm{z}$ nim twarzą $\mathrm{w}$ twarz stanowi konfrontację $\mathrm{z}$ jego prawdziwym obliczem - nie posłusznego przedmiotu na rozkazy, ale samodzielnej jednostki. Twórca to mag, czarodziej stawiający przed rzeczywistością lustro; twórczość to czarodziejski spektakl jako „zwierciadło podstawiane naturze" 58 . Widz siedzi na wprost zwierciadła, które z jednej strony odbija rzeczywistość, ale z drugiej realizuje zamysł twórcy. To już romantyczne myślenie o sztuce i literaturze, o którym pisał wspomniany już wcześniej Abrams. Szekspir realizował wizję teatru jako figury świata.

Problematyka tożsamości postaci-aktora pojawia się z ogromną wyrazistością w dramacie Gwiazda Kajzara. Tytułowa postać to aktorka,

${ }^{57}$ W.H. Auden, Morze i zwierciadto. Komentarz do „Burzy” Szekspira, przel. S. Barańczak, Wydawnictwo a5, Kraków 2003, s. 16.

${ }^{58}$ Tamże, s. 44. 
która opowiada w formie monologu wewnętrznego o swoim życiu - gra swój monodram przed widzami, ale tak naprawdę to właściwie przed samą sobą, przeglądając się w lustrze swojej pamięci. Splatają się wydarzenia rzeczywiste $\mathrm{z}$ życia bohaterki $\mathrm{z}$ granymi rolami, tworząc kalejdoskopową strukturę nierozerwalnych elementów. Aktorskie rozbicie osobowości i dezintegracja własnego „ja” są o wiele bardziej złożone niż innych, „zwyczajnych" ludzi. Podmiotowość ulega totalnemu rozpadowi, „ja" traci swoją wewnętrzną spójność. Kajzar kreśli

obraz człowieka żyjącego wielością wrażeń, impulsów i doznań, i nie potrafiącego, czy nie chcącego, odnaleźć w tej wypełniającej go fali jakiejś własnej miary rzeczy. Owo rozproszenie i wielopostaciowość ,ja” dotyczy tyleż postaci, co wpisanego w tekst autora ${ }^{59}$.

Bohaterka grała własnym życiem/twarzq ${ }^{60}$, aż w końcu zgubiła gdzieś swoją twarz, twarz człowieka z krwi i kości. Jej twarz to roztrzaskane lustro - chaotyczny zbiór fragmentów. Już same formy osobowe, oscylujące między ja a on, czyli między formami żeńskimi a męskimi, wskazują na niespójność tej postaci. Świat wewnętrzny jednostki przyjmuje formę dramatyczną - jest rozpisaną na głosy rozmową $\mathrm{z}$ własnym wnętrzem. Bohaterka oscyluje na granicy schizofrenii i rozdwojenia jaźni. Jej najbardziej nieudaną rolą okazuje się jej własne życie. Ukazuje tożsamościowe kulisy zawodu aktora - osoby publicznej, czyli wystawionej na ciągłą obserwację i ocenę. Bohaterka chciałaby doświadczyć samopoznania, szuka prawdy o sobie jako człowieku i aktorze jednocześnie. Nakłada wciąż to nowe maski i kostiumy, wypowiada słowa własne, jak i swoich scenicznych ról, przywołuje w lustrze pamięci swoją biografię. Próbuje w chaosie odnaleźć swoją własną twarz. Aktorka widzi siebie jako ja-z przyrośniętq maskq, ja-zwierciadto mówiquce ${ }^{61}$.

Teatr jako przestrzeń gry lustrzanych odbić oddaje lustrzaną naturę ludzkiej samoświadomości - wiedzy o samym sobie. Jednocześnie widz również zostaje postawiony przed zwierciadłem sceny, która w myśl Kajzarowskiej koncepcji metateatru ma być punktem wyjścia do własnych przemyśleń i prywatnych prób integracji osobowości. Bo zarówno aktor, jak i widz jest zagrożony rozpadem i niemożnością odnalezienia jakiegokolwiek miejsca wspólnego i łącznika rozsypanych elementów ,ja”. Nie sposób oddzielić życia i jego udawania, rzeczywistości od jej iluzji, rozsupłać splątanych elementów tożsamości.

W kontekście współczesnych dramatów, które od lustrzaności „przeszły na stronę ekranu", tożsamość postaci komplikuje się w stopniu, któ-

${ }^{69}$ E. Wą chocka, Teatr Kajzara, „Sląsk” 2002, nr 10.

${ }^{60}$ H. Kajzar, Gwiazda, s. 127.

61 Tamże, S. 135. 
ry trzeba by nazwać multikomplikacją. Do dramatycznego i teatralnego świata wkraczają już nie tylko światy lustrzane, ale i medialne, komplikując strukturę postaci i utrudniając jej znalezienie punktu czy czynnika integrującego jej ,ja”.

Twórcy dają artystyczne świadectwo kryzysu podmiotu. Podmiot zostaje ujęty jako dynamiczna przestrzeń dramatyczna walki między sferą podmiotową a przedmiotową. Kategoria Inności przenika podmiot, wprowadzając dramatyczną grę na polu tożsamości. „Ja” to już nie efekt negocjacji i wyboru między wieloma wzorcami tożsamości, czyli celowy projekt samego siebie ani też dialogowa struktura (o której pisał Habermas). Jeśli by próbować znaleźć dla niej jakąś nazwę, to przyjmuje charakter performatywny - oparty na powtarzalności istniejących wzorców oraz transwersalny ${ }^{62}$ - wielowymiarowy, pluralny, płynny, oparty na różnicy i nietożsamości, wymagający wysiłku scalania (który nigdy nie jest czynnością skończoną).

Jednak dla dramatycznych rozważań nad tożsamością lepiej użyć terminu plastycznego. Artystyczna technika kolażu staje się sposobem konstrukcji postaci i wyrazem rozbicia ich osobowości. To koncepcja ,ja”, które staje się chwilami nawet zbliżone w swej strukturze do dzieła stworzonego techniką montażu. Jednak zachowuje swój rdzeń - kolażowość. Jeśli przyjąć rozumienie terminu kolaż za Agnieszką Karpowicz ${ }^{63}$, to:

przeistacza reprezentację $w$ uobecnienie. Najważniejsze jednak, że nie jest to imitacja, lecz doświadczenie zmodyfikowane; doświadczenie faktury tapety poza jej funkcją w świecie rzeczywistym. Kolaż jest gestem zbliżania systemu reprezentacji do życia, lecz w sposób całkowicie niemimetyczny; w sposób kreacyjny ${ }^{64}$.

W przypadku budowania tożsamości współczesnych dramatycznych postaci nie można mówić jednoznacznie ani o jednopłaszczyznowym montażu, ani o komponowaniu ,ja" z heterogenicznych elementów gotowych ${ }^{65}$. Nie do końca też wydaje się zasadne przykładanie do współczesnej tożsamości pojęcia patchworku ${ }^{66}$, choć pewne jego cechy, jak uformowanie

$62 \mathrm{~W}$. Welsch, Stajqc się sobq, w: Problemy ponowoczesnej pluralizacji kultury. Wokót koncepcji Wolfganga Welscha, pod red. A. Zeidler-Janiszewskiej, Wydawnictwo Fundacji Humaniora, Poznań 1998.

${ }^{63}$ A. Karpowic z, Kolaż - rzeźbienie rzeczywistości, „Przestrzenie Teorii” 2007, nr 7.

64 Tamże, s. 125.

65 Tamże, s. 126.

$66 \mathrm{Za}$ dominujące $\mathrm{w}$ dyskursie ponowoczesnym przedstawienie tożsamości $\mathrm{w}$ formie patchworku uznaje A. Mankiewicz, Tożsamość czlowieka-poety w twórczości Mirona Biatoszewskiego, w: Literatura i/a tożsamość $w X X$ wieku, red. nauk. A. Glen, I. Jokiel, M. Szladowski, Opolskie Towarzystwo Przyjaciół Nauk, Opole 2007, s. 54. 
z wielu wzajemnie niezależnych od siebie, dość przypadkowych elementów i brak logiki ich układu oraz powielania, można odnaleźć w tożsamościowej konstrukcji. Wyrwane z kontekstu medialne wizerunki, wspóltworzące świadomość postaci w nowym otoczeniu, zachowują pamięć swojej genezy, funkcjonując na zasadzie powtórzenia, ale jednocześnie zyskują w zderzeniu z innym elementami nową wartość. Z drugiej strony dominującą dziś strukturą jest kopia, powtórzenie, oderwanie od kontekstu, iluzja - które są zaprzeczeniem istoty kolażu. Z jednej strony występuje przekraczanie granic między sztuką a rzeczywistością, z drugiej tworzenie sztucznych światów zastępujących ten realny. Choć obrazy filmowe, telewizyjne i cyfrowe powstają na zasadzie montażu mającego stworzyć efekt iluzji i bez wątpienia współtworzą wizerunki dzisiejszych postaci dramatycznych, to są jednym $z$ elementów, a nie jedynym. Poza tym montaż nie jest tak bardzo „płaski”, jak mogłoby się zrazu wydawać - zestawienie dwóch ujęć wywołuje skojarzenia prowadzące do powstania nowych jakości, które mogą również, tak jak kolaż, na swój sposób stawać się częścią rzeczywistości ich odbiorców. Zatem splatają się tu ze sobą iluzyjność, kopiowanie, cytowanie, jak i kreacja, spotykając się na polu tożsamościowych poszukiwań.

Wizerunek postaci, który wyłania się z powyższych refleksji, to obraz homo creatora ${ }^{67}$. Człowiek jest jednostką, która wybiera spośród różnorodnych wzorców tożsamości. Ale nie składa ich w jedną całość. Różne twarze wykorzystuje w odpowiednich (według niego) sytuacjach - zdejmuje i zakłada tożsamościowe maski. Chociaż i to określenie nie wydaje się właściwe - to nie są całościowe maski wyrażające dany typ osoby, ale konglomerat, „zbieranina” elementów w znacznej części zaczerpniętych z przekazów medialnych (jako dominujących we współczesnej kulturze). Nie jest to jednak tylko zbiór, ale pewna całość - heteronomiczna, pełna pustych miejsc, porwana, niestabilna, płynna, która jednak tworzy pewną strukturę. I choć $\mathrm{w}$ rozważaniach o tożsamości narzuca się jako pierwsze skojarzenie z koncepcjami Ricoeura, Sartre'a czy Heideggera, to jednak bliższe są tutaj rozważania wspomnianych już wcześniej Foucaulta, Deleuze'a czy Derridy68. Paul Ricoeur mówił o dwuwymiarowej

67 Określenie homo creator za: E. Krzyżaniak, Nie ma tożsamości darowanej, czyli poszukiwanie siebie w Innym, w: Ekran. Mit. Rzeczywistość, pod red. W.J. Burszty, Wydawnictwo Książkowe Twój Styl, Warszawa 2003, s. 13.

68 Spośród wielu teorii tożsamości wspomnieć też warto w tym kontekście następujące: koncepcję Charlesa Taylora (Żródta podmiotowości: narodziny tożsamości nowoczesnej, przeł. M. Gruszczyński, nauk. oprac. T. Gadacz, wstępem poprzedziła A. Bielik-Robson, Wydawnictwo Naukowe PWN, Warszawa 2001), Henryka Elzenberga (Wartość $i$ człowiek: rozprawy $z$ humanistyki $i$ filozofii, Wydawnictwo Uniwersytetu Mikołaja Kopernika, Torun 2005), Wolfganga Welscha (Nasza postmodernistyczna moderna, przel. R. Kubicki, 
strukturze tożsamości - o poczuciu własnego ,ja”, które kształtuje się w opozycji do Innego oraz o identyfikacji siebie samego poprzez kryteria zewnętrzne natury biologicznej, społecznej i kulturowej. To sprzeczność stawała się źródłem tożsamościowych przemian. Proces i negacja były postrzegane jako źródło kształtowania ,ja” w kolejnych filozofiach. Jednak konfrontacyjno-negacyjny model ciągłego procesualnego tworzenia tożsamości przechodzi na pole performatywności, transgresji i transwersalności69. Inny przestaje być lustrem, w którym ,ja” się przegląda, aby znaleźć swój odpowiednik ${ }^{70}$ poprzez różnicę. Dzisiaj rozpoznanie nie jest już możliwe.

Tożsamość przyjmuje formę hipertekstu. Jest siatką luźno, czasem jedynie niezmiernie cienką nicią połączonych, elementów. Nie sposób nadal stosować narracyjnego ujęcia tożsamości ${ }^{71}$, gdy tożsamość ujmowana jest jako proces znajdujący się $w$ toku rozsadzania ${ }^{72}$. Innym staje się wizerunek - sztuczna kreacja zaczerpnięta z iluzyjnych, umownych światów. Tożsamość indywidualna ksztaltowała się pod wpływem zderzenia tożsamości kulturowej (w tym społecznej, etnicznej, narodowej). Dziś nie ma miejsca na jeden skończony obraz siebie, a za wzorce służą kreacje medialne. Szczególnie wyraźnie widoczny jest proces zacierania granic między wzorcami tożsamości i braku tego dominującego $\mathrm{w}$ internetowej społeczności czatu. Tutaj nick staje się twarzą - tożsamością wymyśloną na potrzeby danej grupy dyskusyjnej. Ale $z$ reguły ten sam użytkownik może mieć wiele pseudonimów oraz dowolnie kreować siebie wobec innych - cały czas stwarza swoje wirtualne ,ja”. Nick nawiązuje albo do jakiejś cechy charakteru osoby, która go przyjmuje, albo wręcz przeciwnie, stwarza wyidealizowany obraz siebie (to najczęstsza strategia). Może się też odwoływać do świata mediów - postaci filmowych, telewizyjnych oraz bohaterów gier komputerowych. Powstaje jeszcze jedna

A. Zeidler-Janiszewska, „Oficyna Naukowa”, Warszawa 1998) czy Clifforda Geertza (Zastane światto: antropoliczne refleksje na tematy filozoficzne, przekł. i wstęp Z. Pucek, Universitas, Kraków 2003).

69 Różnicę między transwersalnością a transgresją widzieć można: transgresja - to przekroczenie, ale i pewna zmiana; transwersalność - to hybrydyzacja - nie tylko przekraczanie granic, lecz wzajemne przekraczanie granic podmiotów lub zjawisk uczestniczących w procesie komunikacji, w wyniku czego następuje ich przenikanie i przemieszanie we wspomnianym procesie hybrydyzacji.

${ }^{70}$ Choć w ten sposób postrzega dzisiejszy model tożsamości badaczka w przywoływanym już powyżej artykule: E. Krzyżaniak, op. cit., s. 19.

${ }^{71} \mathrm{~K}$. Rosner, Narracja, tożsamość $i$ czas, Universitas, Kraków 2003. Autorka podaje narracyjne koncepcje tożsamości następujących filozofów: A. MacIntyre'a, Ch. Taylora, A. Giddensa i D. Carra.

72 A. Kunce, Tożsamość $i$ postmodernizm, Dom Wydawniczy Elipsa, Warszawa 2003, s. 37. 
wersja ,ja" - osobowość on-line $e^{73}$. Jednak wcale nie służy to nabraniu większej świadomości siebie rzeczywistych, bo proces tworzenia przechodzi do sfery realnej. Nie ma już nic stałego i skończonego, tylko nieustanna fluktuacja i przenikanie się elementów z tożsamości internetowych do realnych i na odwrót. W końcu nie sposób już zachować podziałów, granice zostają zatarte - pozostaje tożsamościowy konglomerat - kolaż.

${ }^{73}$ W. Godzic, Na marginesie metafor Sieci, w: Intermedialność $w$ kulturze końca XX wieku, pod red. A. Gwoździa, S. Krzemień-Ojaka, Trans Humana, Białystok 1998, s. 37. 